\title{
Utilization of Lime Sludge Activated by Salt in Egyptian Expansive Soil Improvement
}

\author{
Carmen M. Sharaby ${ }^{1}$, Mohie Eldin M. El mashad ${ }^{2 *}$, Mona A. Fakhry ${ }^{3}$ and Marwa H. Salama ${ }^{4}$ \\ ${ }^{1}$ Faculty of Science, Chemistry Department \\ Al-Azhar University, Egypt \\ ${ }^{2}$ Construction Research Institute, Geotechnical Engineering Department \\ National Water Research Center, Egypt \\ ${ }^{3}$ Faculty of Science, Chemistry Department \\ Al-Azhar University, Egypt \\ ${ }^{4}$ Construction Research Institute, Chemistry Department \\ National Water Research Center, Egypt \\ ${ }^{*}$ Corresponding author's email: elmashad [AT] hotmail.com
}

\begin{abstract}
Expansive soils are active clays which cause engineering problems all over the world. This research deals with the impact of lime sludge (LS) as industrial solid waste from sugar-cane factory and sodium chloride salt ( $\mathrm{NaCl}$ ) on engineering properties of expansive soil. In this research, an analytical study of chemical and physical properties of Egyptian expansive soil in Sixth of October City was made as a case study. The laboratory results showed improvement of chemical, microstructural properties and thus the engineering properties of this soil. The results of chemical analysis showed the ability of soil to improve $\mathrm{pH}$; soil alkalinity raise to the required level of stabilization. After soil treatment, Microstructure scanning electron with energy dispersive spectroscopy (SEM-EDX) analyses showed that new cementitious compounds are formed and soil was changed from a weak dispersed structure to strong flocculated structure. It was also observed by increasing $L S$ and $\mathrm{NaCl}$ concentrations the plastic limit increased and the liquid limit decreased, hence decreased plasticity index; the rate of soil free swelling is decreased due to change of expansive soil texture. Therefore, lime sludge activated by NaCl has positive effects on engineering properties of soil. By this way we protect the environment from industrial solid wastes.
\end{abstract}

Keywords -- expansive soil, swelling, stabilization

\section{INTRODUCTION}

Expansive soils are those which show volumetric changes due to changes in their moisture content. Such soils swell when the moisture content is increased and shrink when the moisture content is decreased. The expansive soils are most likely to be unsaturated and have highly reactive clay minerals called montmorillonite. The expansive soil is widely spread in the Egypt especially in $6^{\text {th }}$ of October City, Obour City, EL-Mokattem City, Badr City, EL-Shorok City, New Cairo City, Katamia City, Nasr City, El- Fayoum City, etc., region, the swelling property of this soil leads to many types of constructional damages [1-20-23].

deformations and failures, involves damages in the roads, shoulders, cracks or failure in foundation of the buildings, and beams and slabs, deformation in the floors, doors and windows. These damages may be simple or moderate or massive depending on the swelling amount. The greatest problem arises when montmorillonite mineral content in soil is high.

The occurrence of expansive clays causes serious stability problems in regions with arid climate. In these areas, the clay is so dry that a supply of a tiny quantity of water may release a fantastic energy capable of producing important damage in structure [29]. Thus, such a soil needs to be improved to be suitable for construction purposes.

On the other hand, the volume of solid waste materials generated from industries, such as lime sludge which generated from sugar industry. The cost of removal of LS is continuing to rise day-by-day in our society. Also disposal of these wastes becomes an environmental danger; this waste pollutes the soil, air and water. Currently, the easily available industrial solid wastes are used to enhance expansive soil properties and become economically sound and environmentally friendly. 
This study aims at the effect of lime sludge on chemical and engineering properties of expansive clayey soil in Egypt; as well as using sodium chloride salt as chemical additive to activate lime sludge and accelerate the reactions.

Typically, lime addition to expansive soils initiates four types of reactions between lime and the silicate/aluminate constituents of the expansive clay. These reactions are flocculation, cation exchange, carbonation and pozzolanic reaction [6-19]. These reactions contribute to mineralogical and microstructural changes in the improved soil.

\section{LITERATURE REVIEW}

The comprehensive review of literatures shows that, a considerable amount of work related to stabilization of characteristics of expansive soil is done worldwide using lime, cement, fly ash, industrial solid wastes as lime sludge to be suitable for construction and to resolve all these construction problems resulting from the expansive soil [26].

Soil stabilization is a common engineering method used to improve the physicochemical properties of problematic soil, to achieve the desired engineering requirements [4]. Chemical stabilization results in modification of soil through chemical reactions taking place between stabilizer and minerals that present in the soil.

Among various chemical stabilization methods accepted for expansive soils, lime stabilization is most widely accepted method for controlling the swell-shrink properties of expansive soils [25].

In civil engineering applications extensive studies have been carried out on stabilization of expansive soils using various additives such lime in a wide range and industrial solid waste materials.

[5-7-8-27] have found that when lime is added to expansive soils in the presence of water, a number of reactions occur leading to the improvement of soil properties. These reactions include cation exchange, flocculation and carbonation.

[3] studied the impact of lime treatment on expansive soil engineering behavior, and they found that both swell percent and swell pressure decreased to zero with addition of a given amount of lime to expansive soils.

[28] conducted an experimental study to evaluate the use of lime sludge as soil stabilizer. Experimental study was conducted on five typical types of expansive soils in Ohio State in America. The results showed that addition of lime sludge reduced the plastic behavior of soil and improved its engineering properties.

[17- 22-24] studied the effect of phosphogypsum (PG) on free swelling, index properties and mineralogical properties of expansive soil. Phosphogypsum is solid waste products produced during phosphate fertilizer production. The results showed that liquid limit, plasticity index and free swelling of expansive soil generally decreased when additive percentages increased. Addition of PG resulted in a change in the soil classification from high plastic clay to low plastic. The strength of the soil increased. Analytical technique $\mathrm{x}$ - ray diffraction showed that Montmorillonite was approximately transformed to a non-swelling clay mineral called Kaolinite and Microcline.

[14] Studied stabilization of Egyptian expansive clayey soil using sodium chloride ( $\mathrm{NaCl})$ and industrial carbonate powder (as lime waste). Carbonate powder is solid waste remaining from sawing and polishing ornamental carbonate rocks. The gained significant improvement in the engineering properties of studied expansive soils indicates high action of the two additives in reducing swelling and plasticity properties, even though the calcined carbonate waste showed higher efficiency than the sodium chloride.

\section{MATERIALS AND METHODS}

In the current research, experimental investigation were carried out in four different lime sludge ratios $(3,6,9$ and $12 \%$ by weight of $6^{\text {th }}$ of October soil) and constant ratios of $\mathrm{NaCl}$ equal to (1,2 and 3\%) as admixture for improvement of expansive soil.

\subsection{Materials}

- Natural soil (S): The natural soil used for this study was obtained from (6 $6^{\text {th }}$ of October City, Egypt). The area is mostly covered by clayey soils. Sufficient care has been exercised to see that the soil samples collected are fairly homogeneous.

- Lime Sludge (LS): lime sludge samples were collected from Abou Korkas sugarcane mill that located in El Menia Governorate, Egypt. LS physicochemical properties were tested in laboratory, and corresponding results are summarized in results in (table 4).

- Sodium Chloride Salt (NaCl): salt is an ionic compound with the chemical formula $\mathrm{NaCl}$ representing a 1:1 ratio of sodium and chloride ions, its white in colour and in the form of crystals, produced by Egyptian Salts and Minerals Company (AMISAL). Salt used to accelerate lime sludge - clay reactions.

- Mixing Water: Distilled water was used in all tests for mixing operations. It helps to bind all the raw materials for giving proper mixture. 


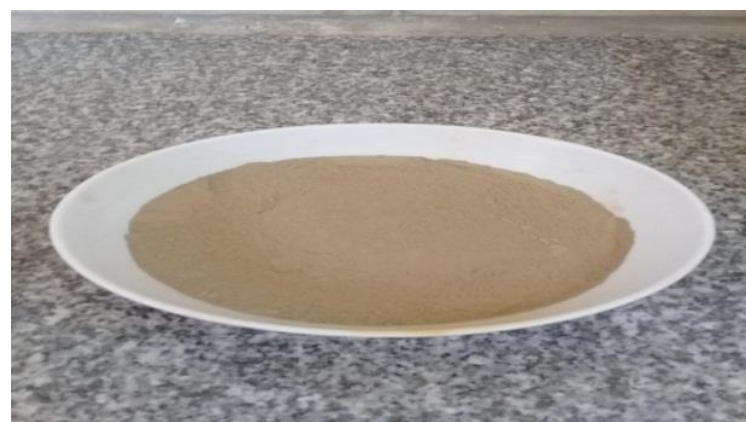

Figure 1: $6^{\text {th }}$ of October soil sample

Soil properties were tested in laboratory, and the corresponding results are summarized in table (1).

Table 1: Physico-chemical properties of $6^{\text {th }}$ of October soil

\begin{tabular}{|c|c|}
\hline Properties & 6 $^{\text {th }}$ of October Soil \\
\hline Colour & Dark green to greenish white \\
\hline Odor & None \\
\hline Hydrogen Ion Concentration $(\mathrm{pH})$ & 8.5 \\
\hline $\begin{array}{c}\text { Electrical Conductivity (EC) } \\
\text { (mmhos/cm) }\end{array}$ & 5560 \\
\hline Total Dissolved Salts (TDS) (\%) & 3.560 \\
\hline Chlorides Content (CL) $(\mathrm{ppm})$ & 1780 \\
\hline Sodium Chloride (NaCl) $(\mathrm{ppm})$ & 2935 \\
\hline Organic Matter (O.M) $(\%)$ & 1 \\
\hline
\end{tabular}

\subsection{Experimental Work}

The experimental work was carried out in the laboratories of the construction research Institute (CRI) of the National Water Research Center (NWRC). The results were examined to determine the chemical, microstructural properties and physical or geotechnical analysis.

Chemical Analysis: The chemical analysis is useful to identify chemical characteristics of expansive soil, additives (lime sludge) and the mixtures that are formed. The chemical analysis determined some main chemical characteristics, e.g. soil reaction $(\mathrm{pH})$, total dissolved solids (TDS), chlorides, oxides and loss on ignition). The chemical data collected from the analysis is tabulated in milligrams per liter $(\mathrm{mg} / \mathrm{L}$ or $\mathrm{ppm})$ and percentage $(\%)$. The chemical analysis of the materials and mixtures were analyzed in chemistry laboratory of the Construction Research Institute (CRI) of the National Water Research Center.

The $\mathrm{pH}$ value of a solution is the negative logarithm of the concentration of hydrogen ions moles per liter; $\mathrm{pH}$ value is determined by measuring the electrical potential of a glass hydrogen ion electrode against a reference electrode of known potential. The $\mathrm{pH}$ is an important indication of the chemical status of the soil. $\mathrm{pH}$ classes are plotted in table (2), [18].

Table 2: Soil $\mathrm{pH}$ classes

\begin{tabular}{|c|c|}
\hline $\mathbf{p H}$ Class & $\mathbf{p H}$ \\
\hline Ultra acid & $<3.5$ \\
\hline Extremely acid & $3.5-4.4$ \\
\hline Very strongly acid & $4.5-5.0$ \\
\hline Strongly acid & $5.1-5.5$ \\
\hline Moderately acid & $5.6-6.0$ \\
\hline Slightly acid & $6.1-6.5$ \\
\hline Neutral & $6.6-7.3$ \\
\hline Slightly alkaline & $7.4-7.8$ \\
\hline Moderately alkaline & $7.9-8.4$ \\
\hline Strongly alkaline & $8.5-9.0$ \\
\hline Very strongly alkaline & $>9.0$ \\
\hline
\end{tabular}


The $\mathrm{pH}$ was determined by means of $\mathrm{pH}$ meter, WTW model LF 538, $\mathrm{pH}$ analysis is made, according to the generally accepted methods described by [11].

Microstructural Analysis: Scanning electron microscopy (SEM) Test has been extensively used to study the morphology of expansive clays and treated expansive clays; SEM with energy dispersive X-ray spectrometer (EDX) has been widely used to identify the composition and nature of minerals in expansive clays and to determine the associations of the minerals with each other. Microstructural analyses of selected samples were carried out using scanning electron microscope (SEM). This test was carried out in laboratories of National Research Center (NRC); the test was performed according to [13].

Table 3: Tested samples for SEM-EDX analysis

\begin{tabular}{|c|c|}
\hline Sample number & Proportions of mix \\
\hline $\mathrm{S}$ & Control sample pure $6^{\text {th }}$ of October Soil \\
\hline $\mathrm{SLNa} 8$ & $12 \% \mathrm{LS}+2 \% \mathrm{NaCl}+86 \% 6^{\text {th }}$ of October Soil \\
\hline
\end{tabular}

Geotechnical Engineering Tests: For geotechnical purposes, a group of different tests can be used to identify the expansive soil/additives mixtures formed, that include, free swelling tests, Atterberg limits (liquid limit, plastic limit and plasticity index). Mixtures were analyzed in the Soil Mechanics and Foundation Laboratory in the (CRI), National Water Research Center (NWRC).

1) Free swell test: (The free swell test is a very important property of expansive soils), the procedure of this test was carried as follows [12].

2) Liquid limit: The liquid limit test was conducted on mixtures using Casagrande's liquid limit apparatus, as per the procedures laid down in [17].

3) Plastic limit: The plastic limit test was conducted on mixtures, as per the specifications laid down in [17].

\section{(A) Chemical Analysis Test Results}

\section{RESULTS AND DISCUSSION}

The chemical analysis of lime sludge and all mixtures were analyzed in chemistry laboratory of Construction Research Institute (CRI), National Water Research Center (NWRC). Physicochemical properties of LS are presented in the following table.

Table 4: physicochemical analysis results of lime sludge

\begin{tabular}{|c|c|}
\hline Properties & Element Content \\
\hline Colour & brownish white \\
\hline Basic characteristics & Sludge \\
\hline Odor & None \\
\hline Hardness & Soft \\
\hline $\mathrm{pH}$ & 7.45 \\
\hline Electrical conductivity $(\mathrm{EC} \mu \mathrm{S} / \mathrm{cm})$ & 5780 \\
\hline Total Dissolved Salts (T.D.S ppm) & 2880 \\
\hline Chloride $\left(\mathrm{Cl}^{-} \mathrm{ppm}\right)$ & 143 \\
\hline $\mathrm{NaCl} \mathrm{ppm}$ & 235 \\
\hline $\begin{array}{l}\text { Variation in Electric Conductivity (EC) } \\
\text { (Pozzolanic Activity) } \mathrm{mS} / \mathrm{cm}\end{array}$ & 0.72 \\
\hline Silica Content $\left(\mathrm{SiO}_{2}(\%)\right.$ & 6 \\
\hline Ferric Oxide $\left(\mathrm{Fe}_{2} \mathrm{O}_{3} \%\right)$ & 2.25 \\
\hline Aluminum Oxide $\left(\mathrm{Al}_{2} \mathrm{O}_{3} \%\right)$ & 0.75 \\
\hline Sulfates $\left(\mathrm{SO}_{3} \%\right)$ & 0 \\
\hline Calcium Oxide $(\mathrm{CaO} \%)$ & 46 \\
\hline Calcium Carbonate $\left(\mathrm{CaCO}_{3} \%\right)$ & 82 \\
\hline Magnesium Oxide $(\mathrm{MgO} \%)$ & 1.5 \\
\hline Organic Matter (O.M) (\%) & 3.5 \\
\hline
\end{tabular}

\section{1- Variation of soil pH or Soil Reaction}

Soil $\mathrm{pH}$, or soil reaction, is an indicator of the acidity or alkalinity of soil and is measured in pH units. In general, when calcium based additives are used to stabilize soils, the $\mathrm{pH}$ of the stabilized soil mixture increases and leads to the 
formation of cementitious compounds by dissolving the silica present in the clay [11]. The immediate effect (after 1 h $\&$ 24h) after mixing LS with the soil, $\mathrm{pH}$ value is presented in the following figures.

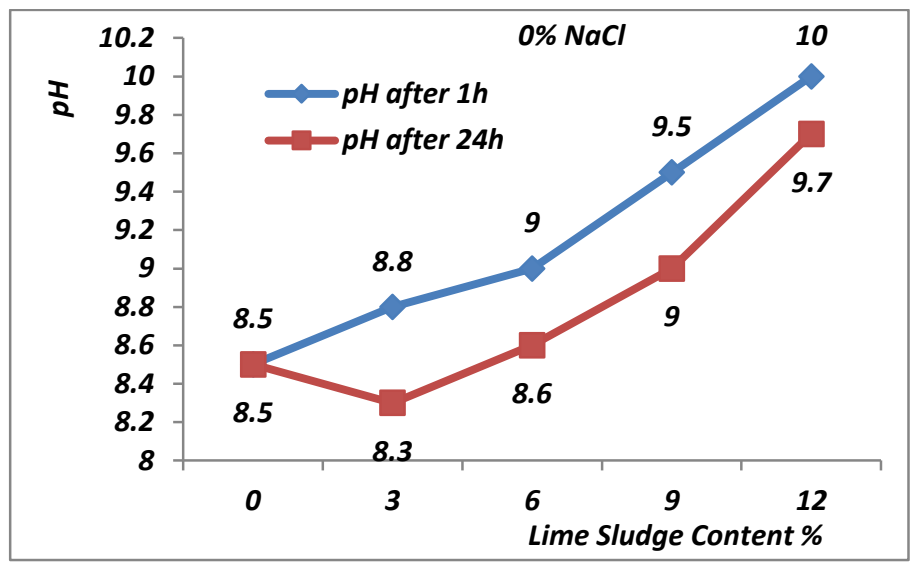

Figure 2: Variation of Soil pH by Addition of Lime Sludge in Different Ratios (3, 6, 9 \&12 \%)

In (figure 2), $\mathrm{pH}$ value of treated soil increased from 8.5 to 10 by increase LS content up to $12 \%$. When lime sludge and $\mathrm{NaCl}$ solutions react with expansive clays, a rich layer of $(\mathrm{Si}-\mathrm{Al}-\mathrm{O})$ forms on the clay particle surfaces. This layer absorbs hydrogen ions $\left(\mathrm{H}^{+}\right)$, resulting in an increase in hydroxide ions $\left(\mathrm{OH}^{-}\right)$and increasing $\mathrm{pH}$ value producing highly alkaline environment; this alkaline environment is suitable for dissolution of $\mathrm{SiO}_{2}$ and $\mathrm{A}_{2} \mathrm{O}_{3}$ of clays.

The $\mathrm{pH}$ value gradually decreases with increasing curing times due to consumption of silica, alumina and $\left(\mathrm{OH}^{-}\right)$ ions due to destroying expansive soil structure and formation of another structure, and more production of cementitious compounds, such as calcium silicate hydrated (CSH), sodium silicate hydrated ( $\mathrm{SSH}$ ) gels, calcium aluminate hydrated $(\mathrm{CAH})$ and sodium aluminate hydrated $(\mathrm{SAH})$ fibrous, as a result from pozzolanic reactions, these hydration products contribute to increase the strength of the soil.

Pozzolanic stabilization reaction is a reaction between lime sludge, $\mathrm{NaCl}$, water, soil silica, and soil alumina resulting in several cementing agents, which cover the soil particles and later crystallize to bonds them, the basic form of the pozzolanic equations is given as follows

$\mathrm{Ca}^{2+}+2 \mathrm{OH}^{-}+\mathrm{SiO}_{2}$ (soluble clay silica) $\rightarrow \mathrm{CSH}$ (Calcium silicate hydrated) (1)

$\mathrm{Ca}^{2+}+2 \mathrm{OH}^{-}+\mathrm{Al}_{2} \mathrm{O}_{3}$ (soluble clay alumina) $\rightarrow \mathrm{CAH}$ (Calcium aluminum hydrated) (2)

$\mathrm{Na}^{+}+\mathrm{OH}^{-}+\mathrm{SiO}_{2}$ (soluble clay silica) $\rightarrow \mathrm{SSH}$ (sodium silicate hydrated)

$\mathrm{Na}^{+}+\mathrm{OH}^{-}+\mathrm{Al}_{2} \mathrm{O}_{3}$ (soluble clay alumina) $\rightarrow \mathrm{SAH}$ (sodium aluminum hydrated)

The calcium silicate gel formed initially coats and binds lumps of clay together. The gel then crystallizes to form an interlocking structure which increases the soil strength [15].Thus, as long as enough residual calcium from lime sludge remains in the system and the $\mathrm{pH}$ remains high enough to maintain solubility, the pozzolanic reaction will continue [9].

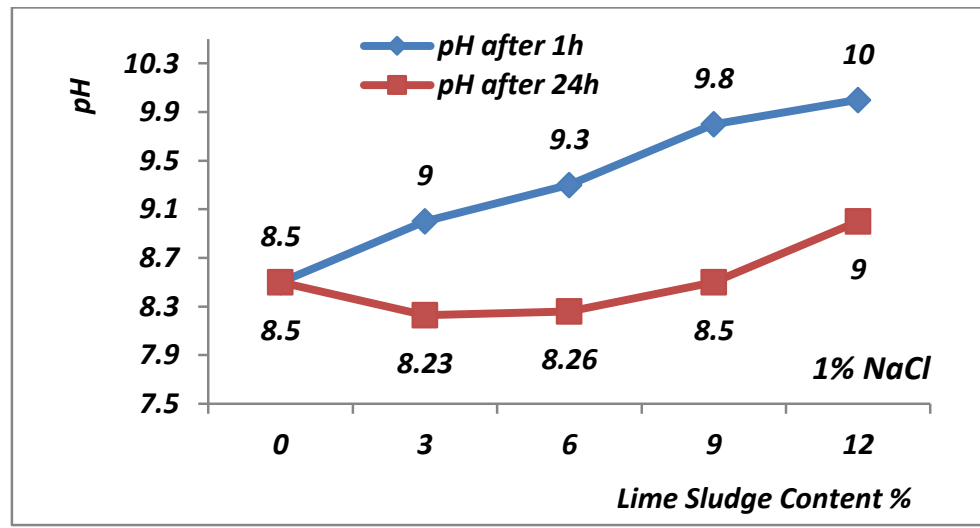

Figure 3: Variation of Soil pH By Addition of Different Ratios of (LS \& 1\% NaCl) 


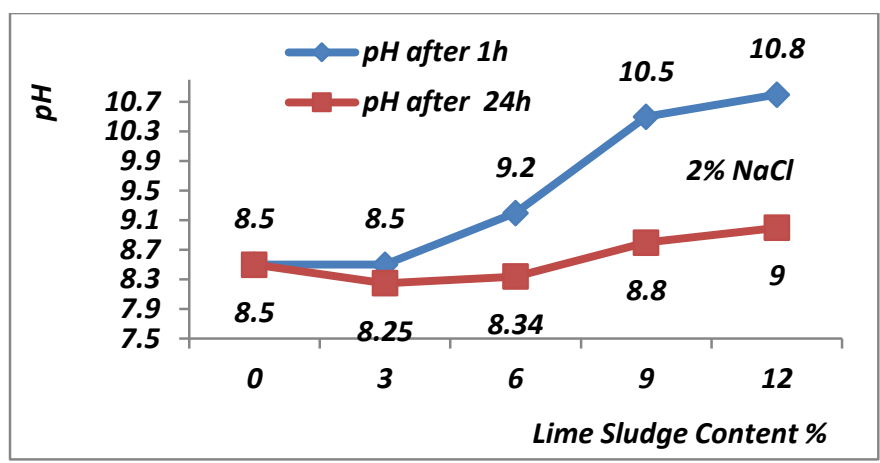

Figure 4: Variation of Soil pH by Addition of Different Ratios of (LS \& $2 \% \mathrm{NaCl}$ )

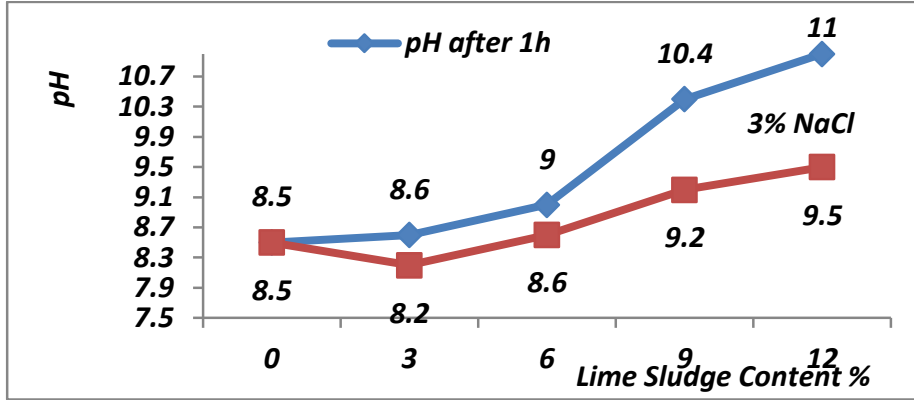

Figure 5: Variation of Soil pH by Addition of Different Ratios of (LS \& 3\% $\mathrm{NaCl}$ )

Figures (3, $4 \& 5)$ respectively showed that when soil treated with different ratios of LS $(3,6,9 \& 12 \%)$ and constant ratio of $\mathrm{NaCl}(1,2 \& 3 \%)$ respectively there is successively increase in $\mathrm{pH}$ by increase in $\mathrm{LS}$ ratio, in the presence of water.

The $\mathrm{pH}$ is observed to decrease after one day for expansive clays treated with lime sludge and sodium chloride. Hence at greater curing period $\mathrm{Ca}^{2+}$ and $\mathrm{Na}^{+}$ions are likely to be dissolved in water and adsorbs on to clay which already be the reason for observed influence of the engineering performance of the soil as free swelling, liquid limit and plasticity index.

\section{2- Oxides Content Test Results}

All examined samples consisted mainly of $\mathrm{SiO}_{2}$, combined $\mathrm{Al}_{2} \mathrm{O}_{3}$ and $\mathrm{Fe}_{2} \mathrm{O}_{3}\left(\mathrm{R}_{2} \mathrm{O}_{3}\right)$ and $\mathrm{CaO}$ in a descending order of abundance and a minor to trace amounts of $\mathrm{MgO}$ of the treated samples were also detected as shown in (table 5).

Table 5: The results of oxides content of soil mixtures

\begin{tabular}{|c|c|c|c|c|c|c|c|c|c|}
\hline \multirow[b]{2}{*}{ Samples } & \multicolumn{3}{|c|}{ Materials used percentage } & \multicolumn{5}{|c|}{ Oxides content } & \multirow{2}{*}{$\begin{array}{c}\left(\mathrm{SiO}_{2}\right. \\
+ \\
\left.\mathrm{R}_{2} \mathrm{O}_{3}\right) \\
\%\end{array}$} \\
\hline & $\begin{array}{c}\mathbf{L S} \\
\%\end{array}$ & $\mathrm{NaCl} \%$ & $\begin{array}{l}\text { Soil } \\
\%\end{array}$ & $\begin{array}{c}\mathrm{SO}_{3} \\
\%\end{array}$ & $\begin{array}{c}\mathrm{SiO}_{2} \\
\%\end{array}$ & $\begin{array}{c}\mathbf{R}_{2} \mathbf{O}_{3} \\
\%\end{array}$ & $\underset{\%}{\mathrm{CaO}}$ & $\underset{\%}{\operatorname{MgO}}$ & \\
\hline $\mathbf{S}$ & 0 & 0 & 100 & 0 & 62 & 9.26 & 6 & 1.2 & 71 \\
\hline SL3 & 3 & 0 & 97 & 0 & 66.5 & 10.3 & 3 & 2 & 77 \\
\hline SL6 & 6 & 0 & 94 & 0 & 66 & 7.2 & 10.5 & 1.6 & 73 \\
\hline SL9 & 9 & 0 & 91 & 0 & 61.7 & 9.3 & 9.7 & 1.2 & 71 \\
\hline SL12 & 12 & 0 & 88 & 0 & 60 & 11.1 & 10.6 & 2 & 71 \\
\hline SLNa1 & 3 & 1 & 96 & 0 & 68 & 9.2 & 7 & 1.8 & 77 \\
\hline SLNa2 & 6 & 1 & 93 & 0 & 65.3 & 8.5 & 8.5 & 1.3 & 74 \\
\hline SLNa3 & 9 & 1 & 90 & 0 & 63 & 9.3 & 12 & 1.7 & 72 \\
\hline SLNa4 & 12 & 1 & 87 & 0 & 59.5 & 8 & 13 & 1.6 & 68 \\
\hline SLNa5 & 3 & 2 & 95 & 0 & 66.3 & 10.3 & 2.8 & 1.8 & 77 \\
\hline SLNa6 & 6 & 2 & 92 & 0 & 63 & 10.3 & 0.9 & 2 & 73 \\
\hline SLNa7 & 9 & 2 & 89 & 0 & 62 & 9.5 & 3.5 & 2.2 & 72 \\
\hline SLNa8 & 12 & 2 & 86 & 0 & 60 & 9.5 & 4.5 & 2.5 & 70 \\
\hline SLNa9 & 3 & 3 & 94 & 0 & 63.5 & 8.5 & 3.3 & 3 & 72 \\
\hline SLNa10 & 6 & 3 & 91 & 0 & 57 & 11.5 & 5 & 2.2 & 69 \\
\hline SLNa11 & 9 & 3 & 88 & 0 & 62.5 & 11.5 & 6 & 3 & 74 \\
\hline SLNa12 & 12 & 3 & 85 & 0 & 59 & 7.3 & 1.5 & 2.5 & 66 \\
\hline
\end{tabular}


The percentage of the main oxides indicated the presence of non-swelling clay, samples which contain $\left(\mathrm{SiO}_{2}+\right.$ $\left.\mathrm{R}_{2} \mathrm{O}_{3}\right)>70 \%$, have a pozzolanic activity and cementitious reactions started and consumption of silica and alumina take place for hydration reaction by increase the additives content as showed in (table 5).

\section{(B) Micro Analysis}

Microstructural analysis discusses the size, shape and arrangement of soil aggregates and pores, SEM-EDX microanalysis was achieved to identify any changes in the elemental composition and physical appearance of the soil after the action of additives. SEM-EDX Analysis of natural soil and soil treated with $(12 \% \mathrm{LS}+2 \% \mathrm{NaCl})$ showed as following.

\section{1) Scanning Electron Microscope (SEM) Analysis}
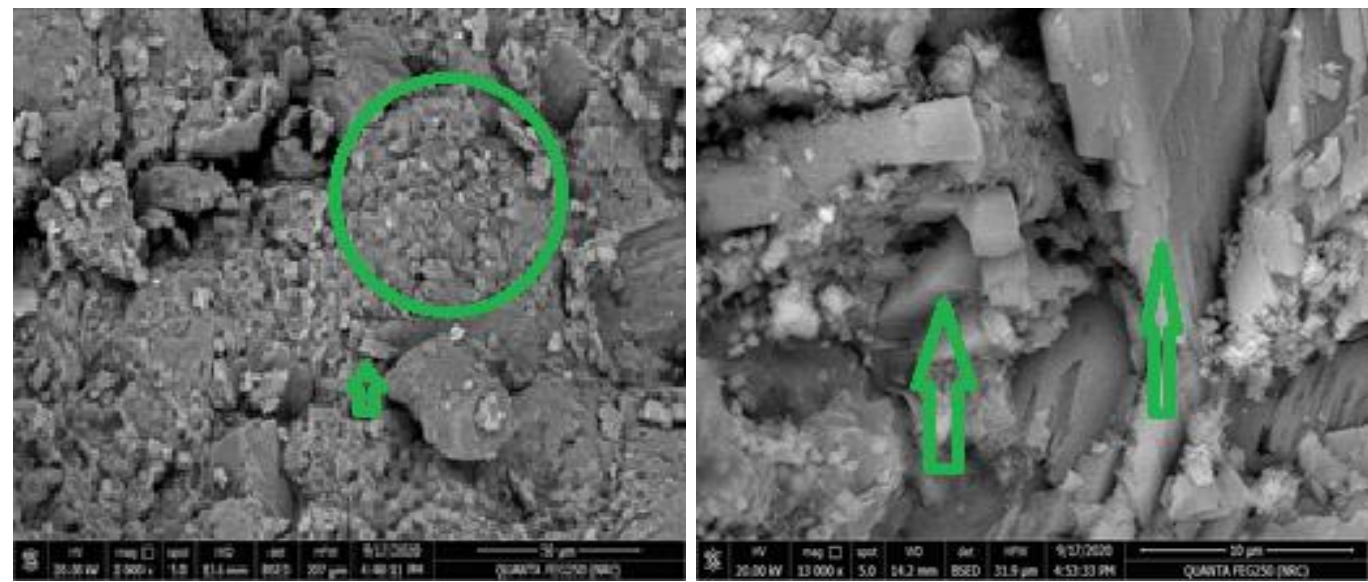

(A)
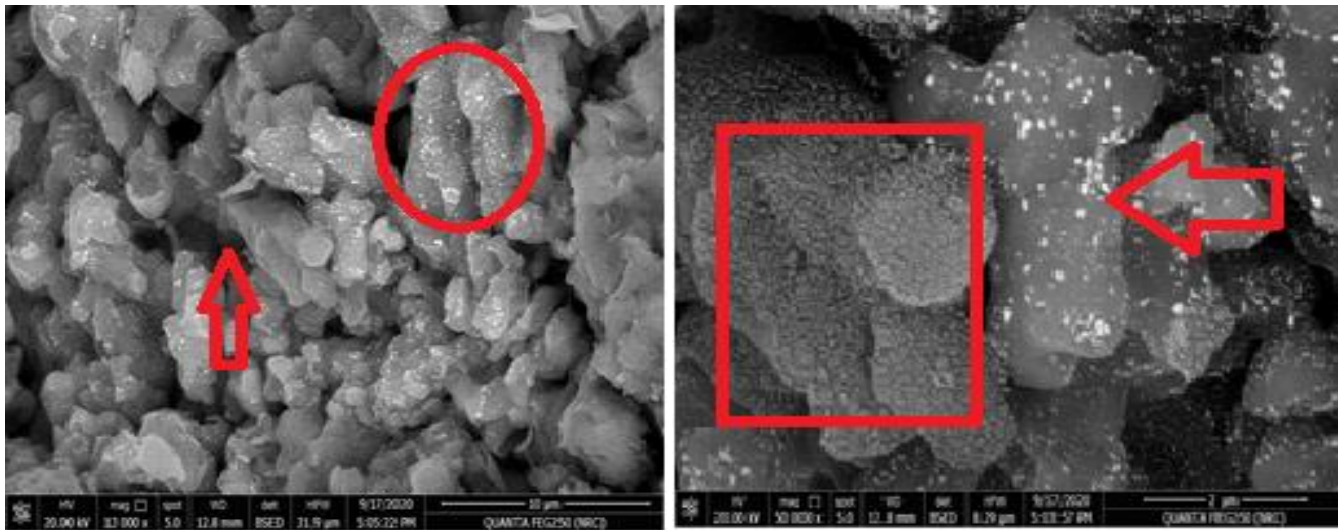

(B)

Figure 6: SEM Micrographs of $6^{\text {th }}$ of October Soil (A) Before Stabilization and (B) After Stabilization

The results of the analysis by scanning electron microscopy (SEM) at magnification 2000 and 13000 times showed that the expansive soil particles have amorphous crystallography, we notice a loose contact between clay crystals and surface was rough as illustrated in figure (6-A), due to presence of montmorillonite platelets (sheet -like particles) with significant deviations in the particle sizes and shapes, Furthermore, crystal growth was also observed on the surfaces of some particles, also the voids are more visible due to the absence of hydration products.

It was found that lime sludge changed the texture of soils. Figure (6-B) showed that there was improvement of the soil structure morphology; the results of SEM of treated expansive soil at magnification 13000 times show high porosity with partially connected pore space. The pores are large, irregular in and separated. By increasing the magnification to 50000 times the irregular shape of particles appear due to generation of better inter-particle cohesion and interlocking, the cementitous products and porous system appeared leading to increase the water infiltration and reduction of plasticity index, The treated soil sample presented cubic $\mathrm{NaCl}$ crystals relatively crystallized, coated with clay in the form of strong flocculated structure in mixture with quartz crystals.

The process of flocculation is essentially responsible for modification of the engineering properties of expansive soils mixed with lime sludge and $\mathrm{NaCl}$. Soil particles were covered by silica and alumina hydrated gels, the calcium silicate and aluminate gel formed initially coats and binds lumps of clay together. Then the gel crystallizes to form an interlocking structure thus; strength of the soils increases [15]. 


\section{2) Energy Dispersive X-ray Spectroscopy (EDX) Analysis}

Energy Dispersive Spectroscopy (EDX) spectral images for expansive soil and quantitative chemical composition data were calculated, figure 7 presents the EDX spectra results of expansive soil particles.

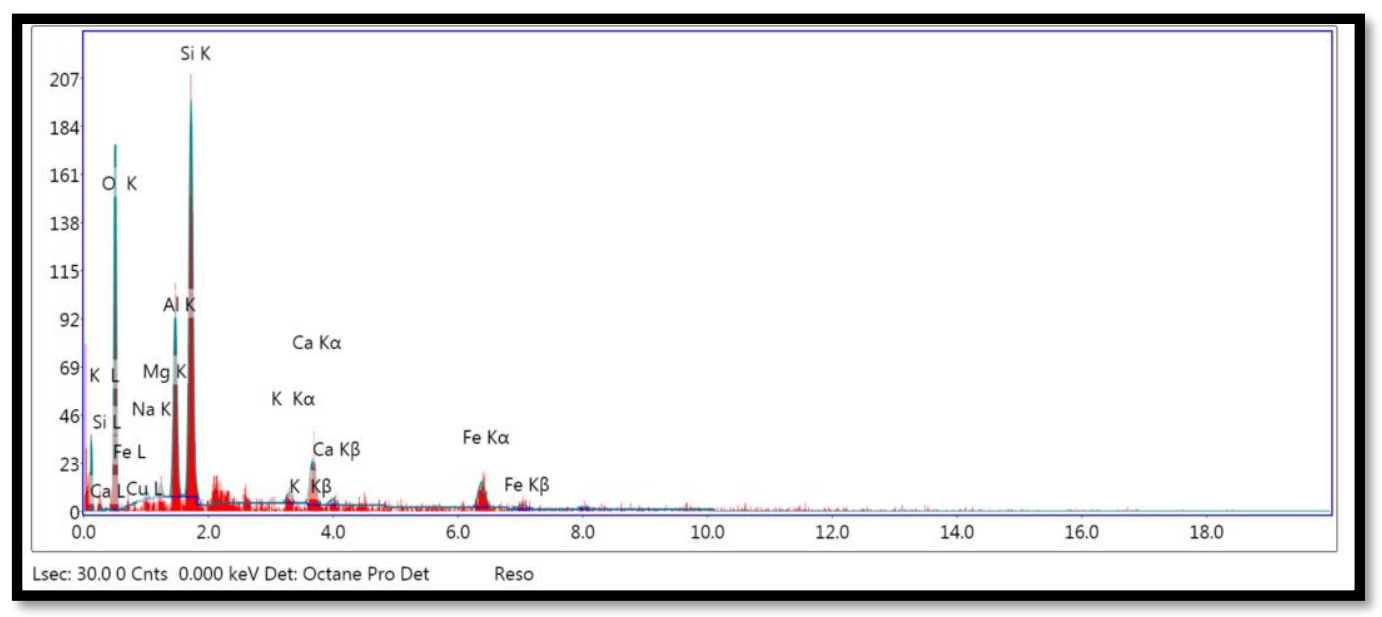

Figure 7: $6^{\text {th }}$ of October Soil EDX Spectra before Stabilization

The results of quantitative analysis on expansive soil have been tabulated in (table 6); the results of the analysis by (EDX) showed that the greatest dominant peak in line spectrum is for silicon then oxygen followed by aluminum. The results of quantitative analysis of $6^{\text {th }}$ of October soil clay particles also are shown in this table. Silicon and oxygen were observed to be the most dominant elements, the other dominant elements were aluminum, iron, calcium, cupper, sodium, potassium followed by magnesium these results support the elemental distribution of montmorillonite-smectites [2-10].

\begin{tabular}{|c|c|c|c|}
\hline Element & $\begin{array}{c}\text { Element } \\
\text { content by } \\
\text { EXD \% }\end{array}$ & $\begin{array}{c}\text { Atomic } \\
\text { weight } \\
\%\end{array}$ & $\begin{array}{c}\text { Standard } \\
\text { formula }\end{array}$ \\
\hline $\mathbf{O}$ & 45.02 & 61.99 & $\mathrm{SiO}_{2}$ \\
\hline $\mathbf{N a}$ & 1.26 & 1.21 & $\mathrm{Na}_{2} \mathrm{O}$ \\
\hline Mg & 1.12 & 1.02 & MgO \\
\hline $\mathbf{A l}$ & 10.95 & 8.94 & $\mathrm{Al}_{2} \mathrm{O}_{3}$ \\
\hline $\mathbf{S i}$ & 24.27 & 19.04 & $\mathrm{SiO}_{2}$ \\
\hline $\mathbf{K}$ & 1.13 & 0.63 & $\mathrm{~K}_{2} \mathrm{O}$ \\
\hline $\mathbf{C a}$ & 5.5 & 3.02 & $\mathrm{CaO}$ \\
\hline $\mathbf{F e}$ & 8.89 & 3.51 & $\mathrm{Fe}_{2} \mathrm{O}_{3}$ \\
\hline $\mathbf{C u}$ & 1.88 & 0.65 & $\mathrm{CuO}$ \\
\hline Totals & 100 & 100.00 & \\
\hline
\end{tabular}

SEM and EDX tests on treated expansive soil has been presented in micrographs illustrated figure (8) and the quantitative data presented in table (7) showed variation from untreated soil peaks of each element between the particles, The dissimilarity in silicon and aluminum elements peaks due to consumption of silica and aluminum in pozzolanic reaction and formation of cementitious compounds as calcium silicate hydrated $(\mathrm{CSH})$ and calcium aluminate hydrated phases $(\mathrm{CAH})$. 


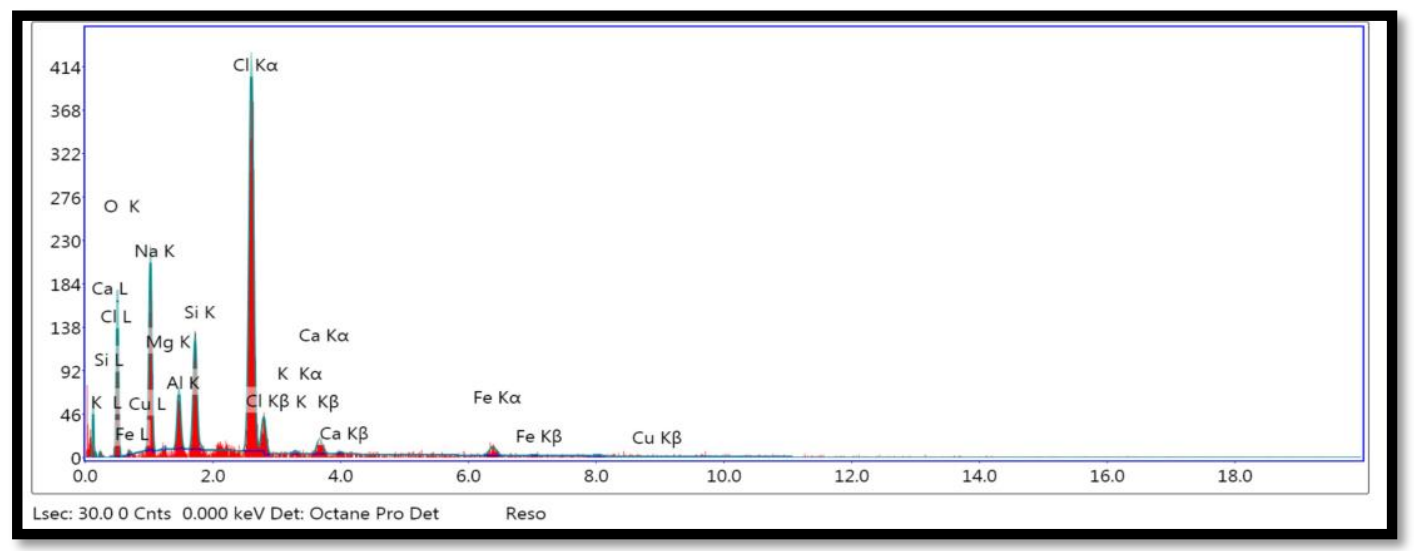

Figure 8: $6^{\text {th }}$ of October Soil EDX Spectra after Stabilization

EDX spectra showed variation in the quantitative chemical composition of each element between the particles of treated $6^{\text {th }}$ of October soil, $\mathrm{NaCl}$ is highlighted in the EDX analysis by peaks of sodium $(\mathrm{Na})$ and chlorine $(\mathrm{Cl})$; chloride associated with the highest peak, The mechanical behavior of the treated sample in the presence of salts is attributed to the effects of the salts on the soil and the modification of the exchange complex ionic structure of the clay. First of all, because of increasing the ionic force of the soil, the diffuse double layer of clay particles is compressed forming cementitious or binding particles that should have been responsible for decreasing free swell. Other elements included oxygen, silicon sodium, aluminum, iron, calcium, cupper, magnesium, and potassium were also found.

Table 7: Quantitative chemical composition of treated $6^{\text {th }}$ of October soil

\begin{tabular}{|c|c|c|c|}
\hline Element & $\begin{array}{c}\text { Element } \\
\text { content by } \\
\text { EXD \% }\end{array}$ & $\begin{array}{c}\text { Atomic } \\
\text { Weight } \\
\%\end{array}$ & $\begin{array}{l}\text { Standard } \\
\text { Formula }\end{array}$ \\
\hline \multicolumn{4}{|c|}{ treated $6^{\text {th }}$ of October soil } \\
\hline $\mathbf{O}$ & 30.28 & 45.07 & $\mathrm{SiO}_{2}$ \\
\hline $\mathrm{Na}$ & 19.61 & 20.31 & $\mathrm{Na} 2 \mathrm{O}$ \\
\hline Mg & 0.53 & 0.52 & MgO \\
\hline Al & 4.35 & 3.84 & $\mathrm{Al}_{2} \mathrm{O}_{3}$ \\
\hline Si & 7.04 & 5.97 & $\mathrm{SiO}_{2}$ \\
\hline $\mathbf{C l}$ & 31.39 & 21.08 & $\mathrm{NaCl}$ \\
\hline $\mathbf{K}$ & 0.29 & 0.17 & $\mathrm{~K}_{2} \mathrm{O}$ \\
\hline $\mathbf{C a}$ & 2.01 & 1.2 & $\mathrm{CaO}$ \\
\hline $\mathbf{F e}$ & 3.12 & 1.33 & $\mathrm{Fe}_{2} \mathrm{O}_{3}$ \\
\hline $\mathbf{C u}$ & 1.38 & 0.52 & $\mathrm{CuO}$ \\
\hline Totals & 100 & 100.00 & \\
\hline
\end{tabular}

\section{(C) Engineering Test Results (Physical Characterization)}

The engineering properties of expansive soil are controlled by chemical constitutions. In association with the chemical compositions tests described above that can determine the engineering properties of this improved soil, there are two basic geotechnical tests that provide fundamental information on the nature of soil materials. These tests are known as the Atterberg limits (liquid limit, plastic limit and plasticity index) and free swelling tests.

\section{Influence of Lime Sludge on Engineering Properties of Expansive Soil}

The addition of $\mathrm{LS}$ and $\mathrm{NaCl}$ affects many of the physical or engineering properties of expansive soil; these properties include free swell (FS), liquid limit (LL), plastic limit (PL) and plasticity index (PI). Following figures showed the physical properties of the studied expansive soil before and after the treatment process. 


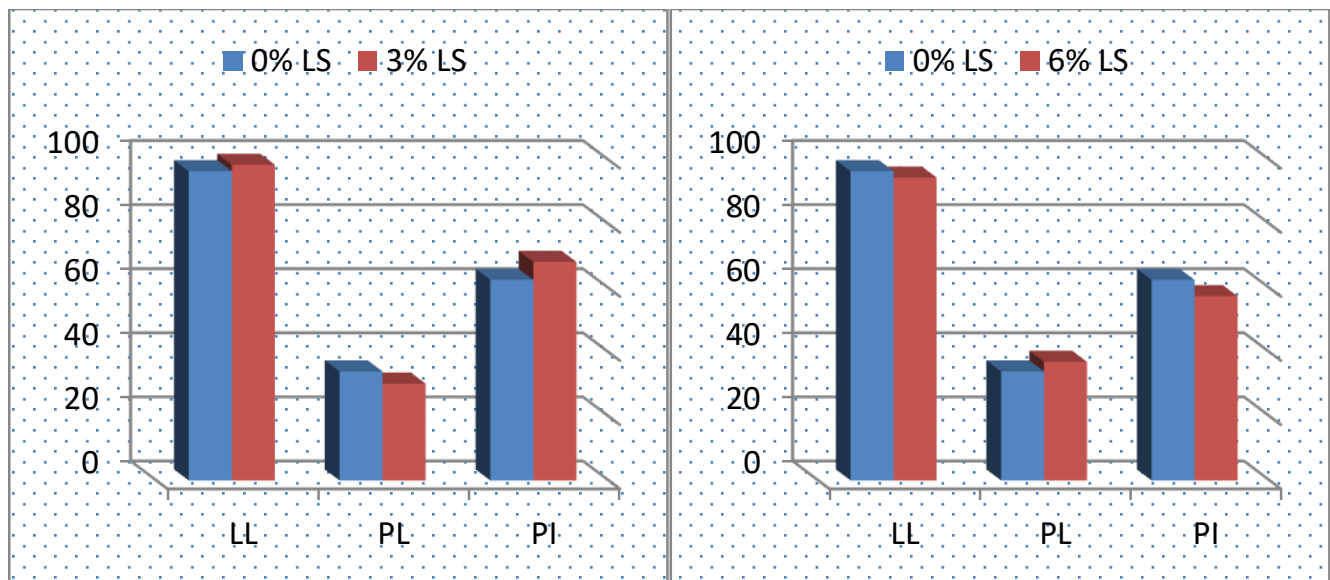

Figure 9: Atterberg Limits and Free Swell at $(0 \%, 3 \%)$ and $(0 \%, 6 \%)$ Lime Sludge Content

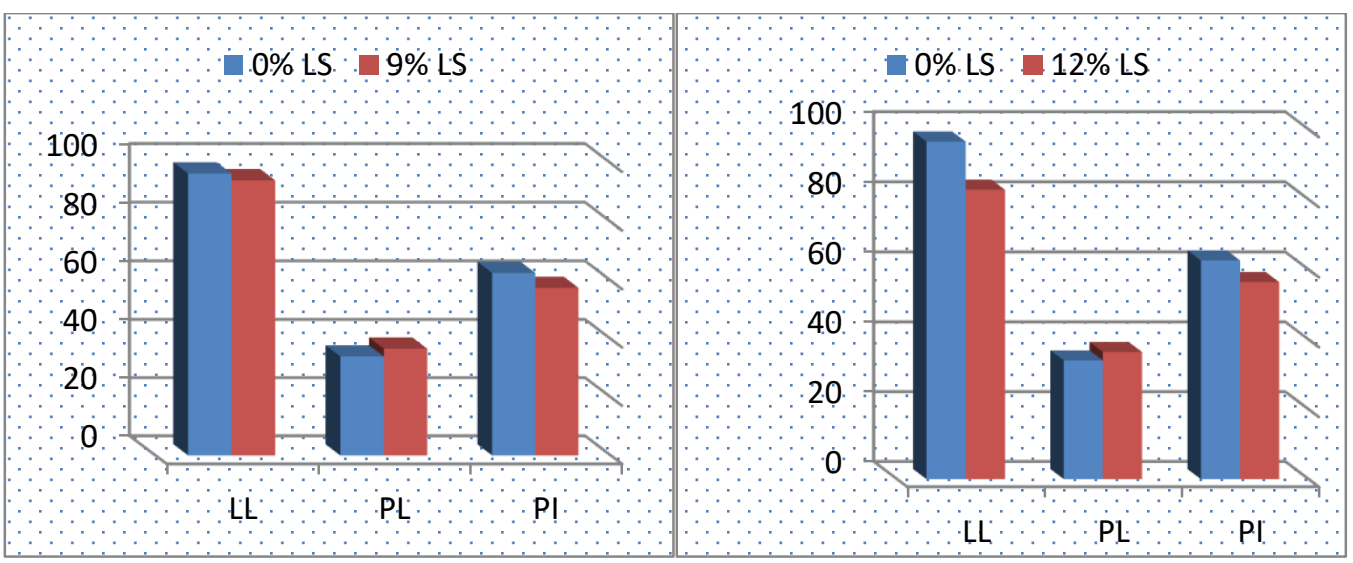

Figure 10: Atterberg Limits and Free Swell at $(0 \%, 9 \%)$ and $(0 \%, 12 \%)$ Lime Sludge Content

Figures (9 \& 10) showed also the Atterberg limits for $0 \%$ and 3, 6, $9 \& 12 \%$ of LS, It can be observed from figures there is reduction in both liquid limit and plasticity index and an increase in plastic limit with the addition of lime sludge.

The liquid limit percent value of the natural studied soil was $96.5 \%$, the liquid limit slightly increased at $3 \%$ LS and decreased to $95,94 \& 93 \%$ when $6,9 \& 12 \%$ of lime sludge was added. The increase is more evident in the plastic limit which increased from $34 \%$ to $36.5 \%$. The reduction in the plasticity from $63 \%$ to $56.5 \%$ makes soil more friable and easily workable. Plasticity decreases because calcium ions from the LS reduce the volumetric changes. Furthermore, the aggregates formed from the flocculation of the soil particles. 


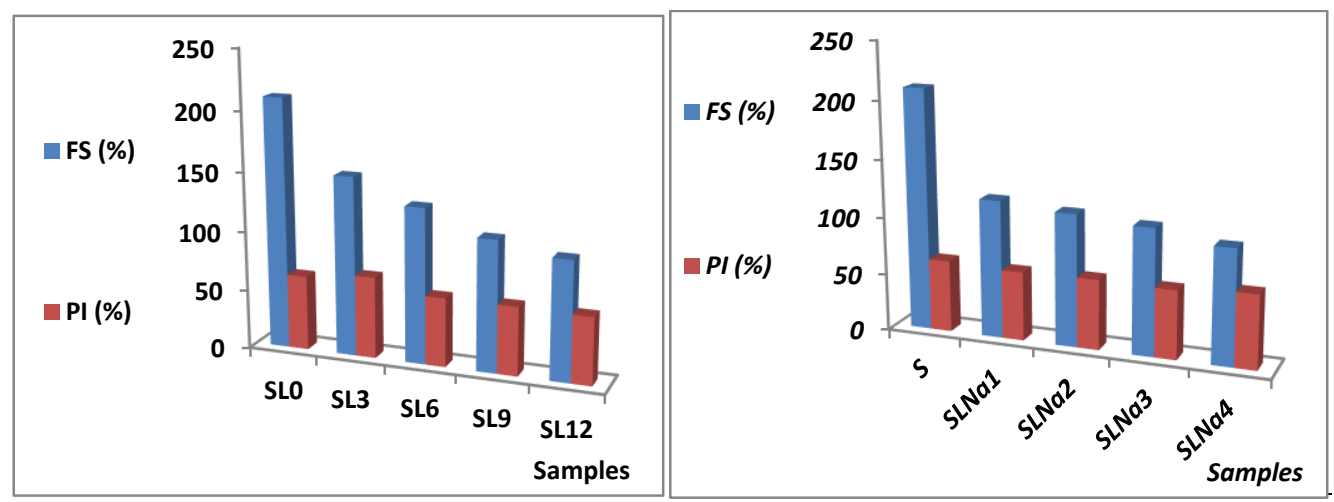

(A) $0 \% \mathrm{NaCl}$

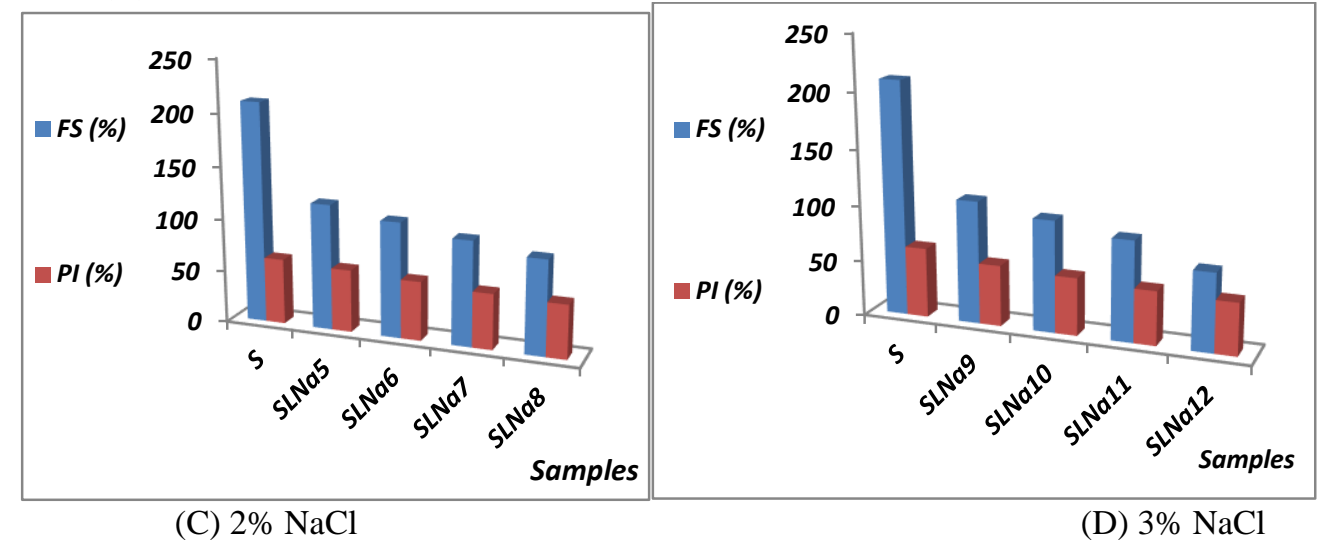

Figure 11: Effect of Additives on Plasticity Index and Free Swelling of $6^{\text {th }}$ of October Soil

Figure (11) showed that the free swelling percent value of the natural studied soil was $210 \%$, the addition of lime sludge only led to a reduction of the free swelling percent from $210 \%$ to $100 \%$. Plasticity index and free swelling of the untreated and treated soil with $\mathrm{LS}$ and $\mathrm{NaCl}$ are shown in figure 11. The results showed that there is a decrease in both plasticity index and free swelling with increasing $\mathrm{LS}$ and $\mathrm{NaCl}$ content which is in agreement with the findings made by [21]. The decrease of the index properties towards less plastic nature indicates that there will be reduction in the swell nature of the stabilized soil.

The results of the geotechnical tests showed that the free swelling of the studied soil sample was $210 \%$ and FS for LS treated soil samples ranged between $100 \%$ and $150 \%$, with an average of $122.5 \%$, FS for (LS + 1\% NaCl) treated soil samples ranged between $100 \%$ and $120 \%$, with an average of $111.2 \%$, FS for ( $\mathrm{LS}+2 \% \mathrm{NaCl}$ ) treated soil samples ranged between $90 \%$ and $120 \%$, with an average of $105 \%$, $\mathrm{FS}$ for ( $\mathrm{LS}+3 \% \mathrm{NaCl}$ ) treated soil samples ranged between $70 \%$ and $110 \%$, with an average of $92.5 \%$, so the results indicate that the use of LS alone, or preferably with $\mathrm{NaCl}$, could have a significant effect on the behavior of the expansive clays.

\section{ACKNOWLEDGMENTS}

We are grateful to the Asian journal of applied sciences, for supporting and continues helping with this work.

\section{CONCLUSION}

1. $\mathrm{LS} \& \mathrm{NaCl}$ can be used as an effective admixture to improve the expansive soil.

2. Utilization of solid wastes not only protects the environment but also improves the engineering properties of the expansive soil.

3. When a small amount of LS is added to the clay test soil, it is thought to create linkages between the clay particles.

4. The first increase in $\mathrm{pH}$ content this may be attributed to the possible formation of some hydration products, after that the consumption of cations for pozzolanic reaction, thereby decrease $\mathrm{pH}$ after $24 \mathrm{~h}$ but $\mathrm{pH}$ still higher than 7; $\mathrm{pH}$ greater than 7 indicates usually a good reactivity to $\mathrm{LS} / \mathrm{NaCl}$ treatment.

5. The microstructural study of stabilized soil indicated destruction of the platy clay particles and formation of cementitious depositions resulting in better aggregation of the soil particles and formation of a compact and dense microstructure.

6. The study showed by using SEM indicated that there is an general improvement in the structure of the clay system resulting in a porous system and aggregate formation 
7. EDX spectra showed variation in the peaks of each element between the particles and so the soil is changed from a weak dispersed structure to a strong flocculated structure.

8. The liquid limit, plastic limit and plasticity index of swelling soil decreases with increasing the ratio of additives.

9. The results of the geotechnical tests showed that the free swelling of the studied soil sample was $210 \%$ and FS for treated soil samples ranged between $70 \%$ and $150 \%$, with an average of $108 \%$; the treatment reduced the swelling of the soil from high to moderate.

10. Increasing the $\mathrm{LS} / \mathrm{NaCl}$ content causes cation exchange to start with a direct effect on the plasticity characteristics of the expansive clayey soil.

From the results of the present study, it can be concluded that, by adding additives of LS and $\mathrm{NaCl}$ with the expansive soil is an effective way to challenge the problem of soil swelling and they are good stabilizer of expansive soil.

\section{REFERENCES}

[1] Al-Mhaidib, A.I., "Characteristics of expansive soil in the kingdom of Saudi Arabia", Journal of King Saud University of engineering science, vol.16, no.1, pp.1-34, 2003.

[2] Al-Mukhtar M., Khattab S., and Alcover J.F., "Microstructure and geotechnical properties of lime-treated expansive clayey soil", Journal of engineering geology. vol.139, no.140, pp.17-27, 2012.

[3] Al-Rawas, A. A., Hago, A. W., and Al-Sarmi, H., "Effect of lime, cement and Sarooj (artificial pozzolan) on the swelling potential of an expansive soil from Oman", Journal of building environment. vol. 40, no. 5, pp. 681-687, 2005.

[4] AI-Sharif, M.M., and Attom M.F., "A geoenvironmental application of burned wastewater sludge ash in soil stabilization", Journal of environmental sciences and engineering, vol.71, no.5, pp. 2453-2463, 2014.

[5] Amer, A.A., and Mattheus F.A.G., "Expansive soils recent advances in characterization and treatment. Proceedings and monographs in engineering", Journal of water and earth sciences, Pp.1-6, 2006.

[6] Arabi, M., and Wild S., "Property changes induced in clay soils when using lime stabilization" Journal of municipal engineer, London, vol.6, pp. 85-99, 1989.

[7] Arvind, K., Baljit S.W., and Asheet B.j., " Influence of fly ash, lime, and polyester fibers on compaction and strength properties of expansive soil", Journal of materials in civil engineering, vol.19, no.3, pp.242-248, 2007.

[8] Basma, A.A., and Tuncer E.R., "Effect of lime on volume change and compressibility of expansive clays", Transportation research board, Washington, no.1296, pp.54- 61, 1991.

[9] Chittoori, B. C. S., "Clay mineralogy effects on long term performance of chemically treated expansive clays", Ph.D. Thesis. Department of civil engineering, University of Texas at Arlington, 2008.

[10] Deer, W.A., Howie, R. A., and Zussman, J., "An introduction to the rock-forming minerals. 3rd ed. London, Mineralogical society of Great Britain and Ireland, 2013.

[11] Eades, J.L., Nicholas, F. P., and Grim, R.E., "Formation of new minerals with lime stabilization as proven by field experiments in Virginia" Highway research board, bulletin, no. 335, pp. 31-39, 1962.

[12] Egyptian Code of Practice of soil mechanics, (ECP) Part 2" Standard test method for free swell test", vol. 202, pp. 142-152, 2001.

[13] Erica, V., "Scanning electron microscope image as a mean to determine dispersibility", M.Sc. thesis. Department of civil engineering. Lowa State University. Ames, Lowa, 2013.

[14] Gehad. M.H., "Stabilization of the Egyptian expansive clayey soil using industrial carbonate waste", Ph.D. thesis. Geology department, faculty of science. Ain shams university, Cairo., Egypt, 2018.

[15] Hadi, N. A., Khoury, H. N., and Suliman, M.R., "Utilization of bituminous limestone ash from EL-Lajjun area for engineering applications. Acta geotechnical journal, Vol. 3, No. 2, Pp.139-151, 2008.

[16] IS: 2720 (Part 5) "Methods of test for soils" Determination of liquid and plastic limit, 1985.

[17] James, J., Lakshmi, S.V., and Pandian, P.K., "Strength and index properties of phosphogypsum stabilized expansive soil", International Journal of applied environmental sciences, vol. 9, no. 5, pp. 2721-2731, 2014.

[18] Joe Scianna, "Salt-affected soils, their causes, measure, and classification" Hort Note no.5, pp.1-3, 2002.

[19] Khattab S., Al-Mukhtar M., Alcover J.F., Fleureau J.M., and Bergaya F., "Microstructure of swelling clay treated with lime. $15^{\text {th }}$ International conference on soil mechanics and geotechnical engineering", Istanbul, vol. 3, pp. 1771-1775, 2001 . 
[20] Khemissa M., and Mahamedi A., " Cement and lime mixture stabilization of an expansive over consolidated clay", Journal of Applied Clay Science vol.95, pp. 104-110, 2014.

[21] Kumar, B., Smitha, Jeevana, N., and Uday K.V., "Effect of salinity on geotechnical properties of expansive soils" International journal of innovative research in science. Engineering and technology, vol.4, no.7, pp.6008-6015, 2015.

[22] Marwa, H. S., "Improvement of swelling soil for constructions by industrial chemical wastes" M.Sc. thesis in applied chemistry. Department of environmental basic science. Ain Shams University, Cairo, Egypt, 2016.

[23] Petry, T.M., and Little, D.N., "Review of stabilization of clays and expansive soils in pavements and lightly loaded structures-history. Practice and future", Journal of materials in civil engineering, vol. 14, no. 6, pp. 447-460,2002.

[24] Sally, M.A., "Treatment of swelling soil using salt and phosphogypsum" M.Sc. thesis. Department of civil engineering, Ain shams university. Cairo, Egypt, 2017.

[25] Thyagaraj.T, Rao,S.M., Sai. P., Suresh, and Salini.U., " Laboratory studies on stabilization of an expansive soil by lime precipitation technique" Journal of materials in civil engineering, vol.24, no.8, pp. 1067-1075, 2012.

[26] Vinay A., and Mohit G., " Expansive soil stabilization using marble dust", International journal of earth sciences and engineering, no.4, pp. 59-62, 2011.

[27] Zhang J., and Cao X., "Stabilization of expansive soil by lime and fly ash", Journal of Wuhan University of technology, vol.50, no.2, pp.191-198, 2002.

[28] Zhang B., and Xiong, Yu., " Experimental evaluation of lime sludge performance in subgrade stabilization", GeoCongress. pp. 3775-3785, 2012.

[29] Zumrawi, M.E., "Construction problems of light structures founded on expansive soils in Sudan. vol.4, no.8, pp.896902, 2015. 